\title{
Circadian Variation in Plasma 17-Hydroxyprogesterone in Patients with Congenital Adrenal Hyperplasia
}

\author{
SHELIA M. ATHERDEN, N. D. BARNES, and D. B. GRANT \\ From The Hospital for Sick Children, Great Ormond Street, London; and the M.R.C. Clinical Research Centre, Watford \\ Road, Harrow, Middlesex
}

\begin{abstract}
Atherden, S. M., Barnes, N. D., and Grant, D. B. (1972). Archives of Disease in Childhood, 47, 602. Circadian variation in plasma 17-hydroxyprogesterone in patients with congenital adrenal hyperplasia. Plasma 17-hydroxyprogesterone (17-OHP) levels in 4 patients with congenital adrenal hyperplasia $(\mathrm{CAH})$ due to 21-hydroxylase deficiency were greatly raised and showed a marked circadian variation, with high morning levels and much lower values during the late evening. This finding indicates that patients with $\mathrm{CAH}$ may require relatively little adrenal suppression during the late evening and early hours of sleep, and suggests that the main suppressive dose of steroid should be reserved for the period between 3.00 a.m. and 3.00 p.m.
\end{abstract}

In the majority of patients with congenital adrenal hyperplasia (CAH), the defect in steroid biosynthesis appears to be due to deficiency of 21-hydroxylase, an enzyme necessary for conversion of 17-hydroxyprogesterone (17-OHP) to 11-desoxycortisol. As a result of this deficiency, excessive amounts of 17-OHP are secreted by the adrenal glands and the plasma levels of 17-OHP in children with CAH may be 50-200 times higher than the values found in normal men (Strott, Yoshimi, and Lipsett, 1969). This paper describes results obtained in 4 patients with $\mathrm{CAH}$ which indicate that there is marked circadian variation in plasma 17-OHP in this condition.

\section{Patients and Methods}

Patients. Four patients with $\mathrm{CAH}$ due to 21hydroxylase deficiency were studied. The first (Case 1), a boy aged 4 years with the simple virilizing form of the disorder, was investigated before any treatment was begun. Two other patients who were not salt-losers were studied 3 days after treatment had been temporarily discontinued. One was a 14-year-old boy (Case 2) who had been treated with steroids since the age of 6 . He had received $5 \mathrm{mg}$ prednisone twice daily for several months before the period of investigation and his urinary 17-oxosteroid excretion had ranged from $7 \cdot 7$ $\mathrm{mg} / 24 \mathrm{hr}$ to $9.3 \mathrm{mg} / 24 \mathrm{hr}$ on this treatment. The other was a 16-year-old girl (Case 3) who had been treated since the age of 1 year. Before investigation she had received $7.5 \mathrm{mg}$ cortisone acetate three times a day and

Received 3 January 1972 the levels of her urinary 17-oxosteroids lay between $6.5 \mathrm{mg} / 24 \mathrm{hr}$ and $7.6 \mathrm{mg} / 24 \mathrm{hr}$. The fourth patient (Case 4), an 18-year-old girl with the salt-losing form of the disorder, was investigated while receiving $25 \mathrm{mg}$ cortisone acetate every 6 hours. Before the period of investigation she had been treated with $50 \mathrm{mg}$ cortisone acetate twice daily and though she showed no gross evidence of virilization, her persistent amenorrhoea suggested that her adrenal hyperplasia was poorly controlled. Her urinary 17-oxosteroid excretion was $26 \cdot 4 \mathrm{mg} / 24 \mathrm{hr}$.

Methods. Venous blood samples were obtained at 11.00 p.m. and 9.30 a.m. in Case 1 . Serial blood samples were obtained at roughly 2-hour intervals for 24 hours in the other 3 patients, using an indwelling intravenous catheter.

Plasma 17-OHP was estimated by a simple proteinbinding technique (Barnes and Atherden, 1972) based on the method of Murphy (1967). Plasma samples were extracted with $2 \%$ ethanol in petroleum ether. Tritiated cortisol and dilute human plasma (CBG) were used to estimate the 17-OHP extracted. Using 0.05 $\mathrm{ml}$ volumes of plasma, the lower limit of sensitivity of the assay is $0.5 \mu \mathrm{g} / 100 \mathrm{ml}$ plasma and the assay is insufficiently sensitive to detect the low levels of plasma 17-OHP found in normal subjects (Strott et al., 1969; Abraham et al., 1971). Details of the precision of the assay have been given elsewhere (Barnes and Atherden, 1972).

The method is not specific for 17-OHP as progesterone is also extracted from plasma. However, as progesterone shows only a $\mathbf{4 0} \%$ competition for CBG when compared with 17-OHP, and as the plasma progesterone 
concentration is only about $3-13 \%$ of that of $17-\mathrm{OHP}$ in CAH (Strott et al., 1969; Simopoulos et al., 1971), the errors caused by this lack of specificity are likely to be small in patients with this condition.

\section{Results}

The results obtained in Case 1 before treatment was started are given in the Table. The plasma 17-OHP level at 11.00 p.m. was $0.7 \mu \mathrm{g} / 100 \mathrm{ml}$, but a second specimen taken at 9.30 a.m. the following morning gave a value of $13.8 \mu \mathrm{g} / 100 \mathrm{ml}$.

\section{TABLE}

Plasma 17-OHP Levels Obtained in Case 1 Before Treatment

\begin{tabular}{rlllll}
\hline \multicolumn{6}{c}{ Plasma $17-$ OH } \\
\hline 2300 & hours & $\ldots$ & $\ldots$ & $\ldots$ & 0.7 \\
0930 hours & $\ldots$ & $\ldots$ & $\ldots$ & 13.8 \\
\hline
\end{tabular}

The results of serial determination of plasma 17-OHP on the remaining 3 patients are shown in the Fig. The two patients who were not receiving treatment showed a fourteenfold to eighteenfold variation in plasma $17-\mathrm{OHP}$ over a 24 -hour period. Both patients had relatively low values between 10.00 p.m. and midnight, but by 3.00 a.m. the levels had risen considerably. In Case 2 a peak level of $23 \mu \mathrm{g} / 100 \mathrm{ml}$ was obtained at 9.00 a.m., but in Case 3 fairly consistent values around $9 \mu \mathrm{g} /$ $100 \mathrm{ml}$ were found between $5.00 \mathrm{a} . \mathrm{m}$. and $11.00 \mathrm{a} . \mathrm{m}$. In both subjects the plasma 17-OHP levels fell progressively during the early afternoon and

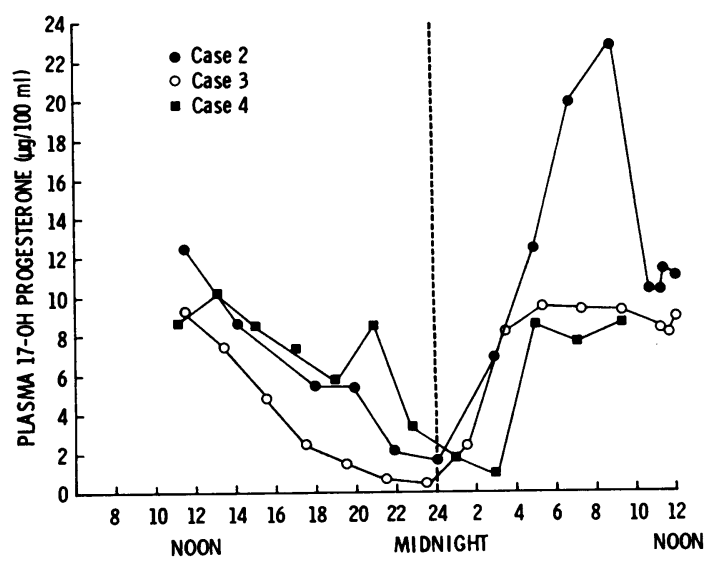

FIG.-Serial plasma 17-OHP levels in 3 patients with $C A H$. Cases 2 and 3 were studied 3 days after treatment had been temporarily withdrawn. Case 4 was investigated while receiving $25 \mathrm{mg}$ cortisone acetate at $6.00 \mathrm{hr}$, $12.00 \mathrm{hr}, 18.00 \mathrm{hr}$, and $24.00 \mathrm{hr}$. evening. Specimens obtained at 15 -minute intervals during the last 45 to 60 -minute period of sampling gave fairly consistent results in each patient.

Considerable variation was also found in the plasma 17-OHP concentration in the patient who was receiving $25 \mathrm{mg}$ cortisone acetate at 6-hourly intervals. This patient showed relatively low levels between 1.00 a.m. and 3.00 a.m., with an abrupt rise during the next 2 hours. The plasma 17-OHP then remained between $8 \mu \mathrm{g} / 100 \mathrm{ml}$ and $10 \mu \mathrm{g} / 100 \mathrm{ml}$ until 3.00 p.m. A further value in this range was obtained at 9.00 p.m., but the remaining results appeared to show a progressive fall in the later afternoon and evening.

\section{Discussion}

Strott et al. (1969) postulated that persistently low plasma levels of cortisol in patients with $\mathrm{CAH}$ would lead to uninhibited ACTH secretion and that, as a result, plasma 17-OHP levels would be maintained at fairly constant high levels. The above results indicate that this is not the case and there appears to be marked circadian variation in the plasma 17-OHP level in CAH due to 21hydroxylase deficiency. This finding is in keeping with the observations that circadian changes in plasma ACTH occur in Addison's disease, despite persistently low plasma cortisol levels (Graber et al., 1965; Besser et al., 1971), and in normal subjects after blockade of cortisol biosynthesis by the 11-hydroxylase inhibitor, metyrapone (Jubiz et al., 1970).

We have recently tried to determine whether estimation of plasma 17-OHP can be of value in assessing treatment in patients with CAH (Barnes and Atherden, 1972). The present results indicate that the timing of such tests must be carefully standardized as estimates obtained during the late afternoon or evening may give misleadingly low values. Estimation of plasma 17-OHP may also be of some diagnostic value in patients with $\mathrm{CAH}$. Our results suggest that the timing of such diagnostic tests may be less important as the plasma 17-OHP levels in all our patients remained abnormally raised during the late evening. The finding of a variation fourteenfold to eighteenfold in plasma 17-OHP indicates that the use of a single morning plasma level to calculate 17-OHP production rate (Strott et al., 1969) is likely to lead to considerable overestimation of the production rate in patients with CAH.

In patients with $\mathrm{CAH}$, one of the main objects of treatment with steroids is to suppress ACTH secretion, thereby reducing adrenal androgen secretion and preventing or reversing virilization. 
The above results indicate that relatively little treatment may be needed during the evening and early hours of sleep, and it appears that the main suppressive dose of steroid is required to cover the period between 3.00 a.m. and 3.00 p.m. Our findings support the suggestion of Hamilton and Moodie (1970) that patients with CAH should be given steroids during the late evening to suppress early morning ACTH secretion. Late evening treatment may have a further advantage. It has been shown that a single dose of dexamethasone given at midnight can suppress ACTH secretion for up to 24 hours (Nichols, Nugent, and Tyler, 1965), and late night treatment of patients with CAH may permit the use of smaller doses of steroid (Hayek, Crawford, and Bode, 1971). Whether such timing of treatment can reduce the risks of steroid-induced growth retardation is still unknown. The results obtained with alternate-day steroid therapy in children with the nephrotic syndrome (Soyka, 1967) indicate that growth suppression is not solely dependent on steroid dose but may also be related to the daily timing of treatment.

We wish to thank Drs. Betty Priestley and G. H. Newns for referring their patients for investigation, and Drs. Geraldine Hill and R. Evans for help in obtaining blood samples.

\section{REFERENCES}

Abraham, G. E., Swerdloff, R. S., Tulchinsky, D., Hopper, K., and Odell, W. D. (1971). Radioimmunoassay of plasma 17hydroxyprogesterone. Fournal of Clinical Endocrinology, 33 42.
Barnes, N. D., and Atherden, S. M. (1972). Diagnosis of congenital adrenal hyperplasia by measurement of plasma 17-hydroxyprogesterone. Archives of Disease in Childhood, 47, 62.

Besser, G. M., Cullen, D. R., Irvine, W. J., Ratcliffe, J. G., and $\overline{\vec{C}}$ Landon, J. (1971). Immunoreactive corticotrophin levels in adrenocortical insufficiency. British Medical fournal, 1, 374.

Graber, A. L., Givens, J. R., Nicholson, W. E., Island, D. P., and Liddle, G. W. (1965). Persistence of diurnal rhythmicity in plasma ACTH concentrations in cortisol-deficient patients. fournal of Clinical Endocrinology, 25, 804.

Hamilton, W., and Moodie, T. (1970). The treatment of congenital adrenal hyperplasia with aminoglutethimide. Developmental Medicine and Child Neurology, 12, 618.

Hayek, A., Crawford, J. D., and Bode, H. H. (1971). Single dose dexamethasone in treatment of congenital adrenocortical hyperplasia. Metabolism, 20, 897.

Jubiz, W., Matsukura, S., Meikle, A. W., Harada, G., West, C. D., and Tyler, F. H. (1970). Plasma metyrapone, adrenocorticotrophic hormone, cortisol, and desoxycortisol levels : sequential changes during oral and intravenous metyrapone administration. Archives of Internal Medicine, 125, 468.

Murphy, B. E. P. (1967). Some studies of the protein-binding of steroids and their application to the routine micro and ultramicro measurement of various steroids in body fluids by competitive protein-binding radioassay. Fournal of Clinical Endocrinology, 27, 973.

Nichols, T., Nugent, C. A., and Tyler, F. H. (1965). Diurnal variation in suppression of adrenal function by glucocorticoids. Fournal of Clinical Endocrinology, 25, 343.

Simopoulos, A. P., Marshall, J. R., Delea, C. S., and Bartter, F. C. (1971). Studies on the deficiency of 21-hydroxylation in patients with congenital adrenal hyperplasia. Fournal of Clinical Endocrinology, 32, 438.

Soyka, L. F. (1967). Treatment of the nephrotic syndrome in childhood. Use of an alternate-day prednisone regimen. American fournal of Diseases of Children, 113, 693.

Strott, C. A., Yoshimi, T., and Lipsett, M. B. (1969). Plasma progesterone and 17-hydroxyprogesterone in normal men and children with congenital adrenal hyperplasia. Fournal of Clinical Investigation, 48, 930.

Correspondence to Dr. D. B. Grant, Division of Infant Development, Clinical Research Centre, Watford Road, Harrow, Middlesex HA1 3UJ. 